\title{
PENDUGAAN MODEL PERAMALAN VOLUME IMPOR PAKAN TERNAK
}

\section{FORECASTING MODELS VOLUME OF ANIMAL FEED IMPORT}

\author{
Herlena Bidi Astuti $\stackrel{\square}{ }$, Linda Harta, Wawan Eka Putra, Emlan Fauzi dan Yesmawati \\ Balai Pengkajian Teknologi Pertanian Bengkulu \\ Corresponding author: lenabidi@gmail.com
}

\begin{abstract}
ABSTRAK
Pakan merupakan unsur penting dalam pengembangan usaha peternakan dan untuk memenuhi kebutuhan dalam negeri masih harus dilakukan impor. Penelitian ini bertujuan untuk menguji model peramalan terbaik volume impor pakan ternak. Data yang digunakan adalah volume impor bulanan dari 2015:1-2019:9. Tiga model dalam analisis yaitu Moving Average, exponensial smoothing dan simple linear regression. Pemilihan model terbaik didasarkan pada pada nilai MAPE, MAD dan MSD atau MSE. Hasil penelitian menunjukkan bahwa model peramalan terbaik adalah metode Simple Linear Regression.
\end{abstract}

Kata kunci: pendugaan; impor; pakan; ternak;

\section{ABSTRACT}

Feed is an important element in developing livestock business. At present, imports are still needed to meet domestic needs. This study aims to examine the best forecasting model for the volume of animal feed imports. The data used are monthly import volume data from 2015: 1-2019: 9 used for this study and three models namely Moving Average, exponential smoothing and simple linear regression. the selection of the best model is based on the value of MAPE, MAD and MSD or MSE. The results showed that the best forecasting model was the Simple Linear Regression method.

Keywords: estimation, import, feed, livestock.

\section{PENDAHULUAN}

Pakan adalah bahan yang dapat dimakan, dicerna dan diserap baik secara keseluruhan atau sebagian dan tidak menimbulkan keracunan atau tidak mengganggu kesehatan hewan ternak yang mengkonsumsinya (Kamal, 1998). Pakan harus memiliki persyaratan disukai, dapat dicerna dan diabsorpsi serta memberikan manfaat bagi ternak. Pakan berfungsi sebagai pembangunan dan pemeliharaan tubuh, sumber energi, produksi, dan pengatur proses-proses dalam tubuh. Kandungan zat gizi yang harus ada dalam pakan adalah protein, lemak, karbohidrat, mineral, vitamin dan air. Berdasarkan kandungan zat gizinya bahan pakan dapat dikelompokkan dalam 5 kelompok yaitu : 1) pakan sumber energi yaitu pakan yang mengandung protein kurang dari 20\%, 
serat kasar kurang dari $18 \%$ dan kandungan dinding sel kurang dari 39\% 2) pakan sumber protein yaitu pakan yang mengandung protein lebih dari 20\% 3) sumber mineral 4) sumber vitamin 5) pakan tambahan/Feed aditif (Subekti, 2009).

Saat ini negara kita masih mengimpor hasil ternak berupa daging, susu, dan telur guna memenuhi kebutuhan protein hewani masyarakat. Penyebab belum mampunya negara kita untuk dapat memenuhi kebutuhan protein hewani masyarakat tersebut disebabkan oleh karena jumlah ternak yang masih kurang juga disebabkan oleh karena masih rendahnya tingkat produktivitas ternak yang diusahakan oleh masyarakat (Syam et al., 2016). Penyebab masih rendahnya tingkat produktivitas ternak kita tersebut dipengaruhi oleh banyak faktor, diantaranya adalah ketersediaan pakan yang tidak menentu. Untuk memenuhi ketersediaan ini pemerintah masih harus impor. Lebih lanjut untuk menjaga kestabilan produktivitas ternak diperlukan monitoring terhadap kebutuhan pakan ternak terutama ketika pakan tidak bisa dipenuhi oleh produksi dalam negeri. dengan demikian penelitian ini adalah untuk menentukan metode peramalan terbaik dari volume impor pakan ternak.

\section{METODE PENELITIAN}

Penelitian ini menggunakan data bulanan volume impor pakan ternak bersumber dari Pusat Data dan Sistem Informasi Pertanian yang terdiri dari 57 periode (bulan) dari tahun 2015-2019 atau 57 observasi. Model yang digunakan dalam model ini adalah sebagai berikut:

\section{Model Moving Average (MA)}

Metode rata-rata bergerak merupakan metode peramalan menggunakan sejumlah data aktual dari permintaan yang lalu dengan kurun waktu jenjang periode tertentu (Sukiyono dan Rosdiana, 2018). Metode ini paling sering digunakan dan paling standar. Tujuan utama dari penggunaaan rata-rata bergerak adalah untuk menghilangkan atau mengurangi acakan dalam deret waktu. Teknik rata-rata bergerak dalam deret waktu terdiri dari pengambilan suatu kumpulan nilai-nilai yang diobservasi, mendapatkan rata-rata dari nilai ini, dan kemudian menggunakan nilai rata-rata tersebut sebagai ramalan untuk periode yang akan datang Moving average adalah suatu metode peramalan umum dan mudah untuk menggunakan alat-alat yang tersedia untuk analisis teknik, (Wardah dan Iskandar, 2016). Secara statistik, model moving average dapat ditulis sebagai berikut:

$$
S_{t+1}=\frac{X_{t}+X_{t-1}+\ldots+X_{t-n+1}}{n}
$$


Dimana $\mathrm{S}_{\mathrm{t}-1}=$ peramalan untuk period ke $\mathrm{t}$ $+1 ; X_{t}=$ data pada periode $t ; n=$ jangka waktu moving average dan nilai $n$ merupakan banyaknya periode dalam rata-rata bergerak (Garpersz, 2008 dalam Sukiyono dan Rosdiana, 2018).

\section{Model Exponential Smoothing}

Metode exponential smoothing adalah prosedur perbaikan yang dilakukan secara terus-menerus pada peramalan terhadap data yang terbaru (Faisol dan Aisah, 2016). Dapat dijelaskan bahwa selanjutnya setiap data diberi bobot dimana bobot yang digunakan disimbolkan dengan a. Simbol a bisa ditentukan secara bebas, yang mengurangi forecast error. Nilai konstanta pemulusan a dapat dipilih diantara nilai 0 dan $0<\mathrm{a}<1$. (Garpersz, 2008 dalam Sukiyono dan Rosdiana, 2018)

$$
S_{t+1}=a X_{t}+(1-a) S_{t}
$$

Dimana $\mathrm{S}_{\mathrm{t}+1}=$ Merupakan nilai ramalan untuk periode berikutnya; $\mathrm{a}=$ konstanta penulisan $(0-1) ; X_{t}=$ data pada perode $\mathrm{t} ; \mathrm{St}=$ nilai penulisan yang lama atau rata-rata yang dimuluskan hingga periode $\mathrm{t}-1$. Nilai a yang menghasilkan tingkat kesalahannya yang paling kecil adalah yang dipilih dalam peramalan

\section{Model Simple Linear Regression}

Metode simple linear regression berusaha untuk menyesuaikan garis melalui berbagai data dari waktu kewaktu, Analisis regresi telah lama dikembangkan untuk mempelajari pola dan mengukur hubungan statistik antara dua atau lebih peubah (variabel). Teknik analisis yang mencoba menjelaskan hubungan antara dua peubah atau lebih khususnya antara peubah-peubah yang mengandung sebab akibat disebut analisis regresi. (Sulistyono dan Sulistiyowati, 2017). secara matematika dapat ditulis sebagai berikut :

$$
Y t=a+\beta X
$$

Dimana Yt merupakan nilai peramalan a adalah nilai konstanta dan $\beta$ merupakan nilai koefisensi regresi variable independen.

\section{Pengukuran Akurasi Hasil Peramalan}

Indikator yang digunakan dalam penentuan model peramalan terbaik adalah dengan melihat nilai rata-rata kesalahan absolut, (MAD), rata-rata kesalahan kuadrat (MSE), dan rata-rata persentase kesalahan absolut (MAPE). Nilai MSE ini diperoleh melalui selisih antara nilai aktual dengan nilai peramalan yang dikuadratkan dibagi dengan banyaknya deret waktu peramalan. Nilai MSE (Mean Sqared Error) digunakan ketika besarnya residual merata sepanjang pengamatan. Nilai MAPE (Mean Absolute Percentage Error) digunakan untuk melihat sejauh mana bias metode peramalan yang digunakan. (Nugraha dan Suletra, 2017). 
HASIL DAN PEMBAHASAN

Statistik Deskripsi Data Volume Impor

Pakan

Berdasarkan data volume impor pakan ternak terjadi fluktuasi dan tidak stabil. Hasil ringkasan statistic data volume impor pakan ternak bulanan ditampilkan pada tabel 1 .

Tabel 1. Hasil Ringkasan Statistic Data Volume Impor Pakan Ternak Bulanan

\begin{tabular}{lr}
\hline Uraian & Nilai \\
\hline Mean & 62.612 .225 \\
Median & 61.600 .408 \\
Standar Deviasi & $11.783 .821,6$ \\
Maksimum & 95.234 .285 \\
Minimum & 38.958 .222 \\
\hline
\end{tabular}

Metode Moving Average (MA)

Pada dasarnya, Moving

Average atau Rata-rata bergerak adalah metode peramalan yang menghitung rata-rata suatu nilai runtut waktu dan kemudian digunakan untuk memperkirakan nilai pada periode selanjutnya (Rizal, 2018) dan (Nurlifa dan Kusumadewi, 2017). Moving Average atau
Rata-rata Bergerak diperoleh melalui penjumlahan dan pencarian nilai rata-rata dari sejumlah periode tertentu, kemudian menghilangkan nilai terlamanya dan menambah nilai baru. Metode moving average dilakukan untuk melihat peramalan trend dari volume impor pakan ternak dan didapatkan hasil pada Tabel 2.

Tabel 2. Hasil Ramalan dengan Metode MA

\begin{tabular}{rlr}
\hline No. & \multicolumn{1}{c}{ Uraian } & Nilai \\
\hline 1. & Nilai Peramalan $(\mathrm{Kg})$ & 70.874 .524 \\
2. & $\quad$ Kriteria Nilai Error pada Metode MA & \\
& a. MSE atau MSD & 2,53 \\
& b. MAPE & 19,05 \\
c. MAD & $11.563 .149,89$ \\
d. Bias & $426.416,9$ \\
\hline
\end{tabular}




\section{Metode Exponential Smooting}

Penghalusan exponensial adalah teknik peramalan rata-rata bergerak dengan pembobotan dimana data diberi bobot oleh sebuah fungsi exponential. Penghalusan eksponensial mirip dengan metode peramalan rata-rata. Setiap data diberi bobot, dimana bobot yang digunakan disimbolkan dengan $\alpha$. Simbol $\alpha$ bisa ditentukan secara bebas, yang mengurangi forecast error. Nilai konstanta pemulusan, $\alpha$, dapat dipilih diantara nilai 0 dan, karena berlaku: $0<\alpha<1$ (Hadinata. 2017). Hasil estimasi dengan berbagai nilai $\alpha$ ditampilkan pada tabel 3.

Berdasar tabel 3 dapat dilihat bahwa nilai kriteria kebaikan model dengan nilai error yang paling kecil adalah metode Single Exponential dengan $\alpha=0,2$. Dimana perolehan nilai MSE 1,49, MAD sebesar 9028325 dan MAPE sebesar 14,62.

Tabel 3. Nilai Eror pada Metode Single Exponential Smoothing

\begin{tabular}{crrr}
\hline$\alpha$ & MSE atau MSD & MAPE & \multicolumn{1}{l}{ MAD } \\
\hline 0,1 & 1,51 & 14,81 & 9.333 .272 \\
0,2 & 1,49 & 14,62 & 9.028 .325 \\
0,3 & 1,52 & 14,99 & 9.207 .582 \\
0,4 & 1,57 & 15,36 & 9.405 .556 \\
0,5 & 1,64 & 15,82 & 9.650 .903 \\
0,6 & 1,74 & 16,25 & 9.880 .844 \\
0,7 & 1,87 & 16,65 & 10.087 .447 \\
0,8 & 2,04 & 17,10 & 103.32 .225 \\
0,9 & 2,24 & 17,86 & 10.805 .175 \\
\hline
\end{tabular}

\section{Metode Simple Linear Regression}

Tabel 4. Hasil Ramalan dengan Metode Simple Linear Regression

\begin{tabular}{rlr}
\hline No. & \multicolumn{1}{c}{ Uraian } & \multicolumn{1}{c}{ Nilai } \\
\hline 1. & Nilai Peramalan $(\mathrm{Kg})$ & $67.844 .201,8$ \\
2. & $\quad$ Kriteria Nilai Error pada metode MA & \\
& a. MSE atau MSD & 1,33 \\
& b. MAPE & 14,29 \\
& c. MAD & 8.548 .125 \\
\hline
\end{tabular}




\section{Pemilihan Model Terbaik}

Pemilihan model terbaik dilakukan

dalam meramal volume impor pakan dengan membandingkan nilai MSE, ternak adalah metode Simple Linear MAPE dan MAS dari masing-masing terpilih seperti yang ditampilkan pada Tabel 5.

Dari tabel 5 dapat dilihat bahwa model peramalan terbaik untuk digunakan Regression dengan nilai MSE 1,33. Dan nilai peramalan volume impor 67.844.201,8 Kg. Secara grafik perbandingan ketiga metode ini dapat dilihat pada gambar 1, 2, dan 3 .

Tabel 5.Perbandingan Kriteria Kebaikan Antar Metode.

\begin{tabular}{lccrr}
\hline \multicolumn{1}{c}{ Model Peramalan } & \multicolumn{1}{c}{ MSE } & \multicolumn{1}{c}{ MAPE } & \multicolumn{1}{c}{ MAD } \\
\hline MA & & 2,53 & 19,05 & $11.563 .149,89$ \\
Exponential & Smooting & 1,49 & 14,62 & 9.028 .325 \\
$\begin{array}{l}(\alpha=0,2) \\
\text { Simple Linear Regression }\end{array}$ & 1,33 & & \\
\hline
\end{tabular}

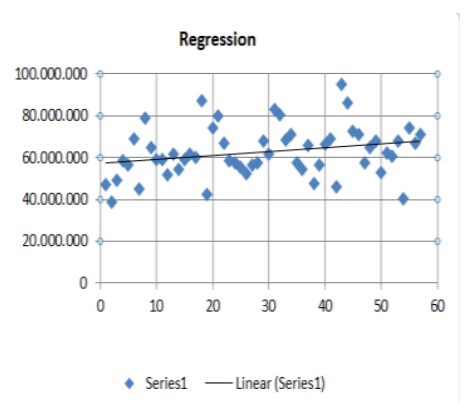

Gambar 1. Simple Linear Regression

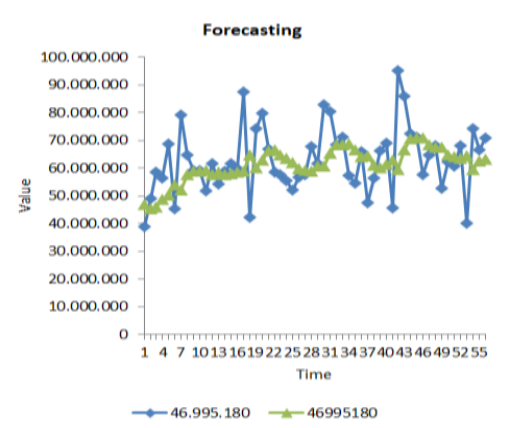

Gambar 2.

Exponential Smooting $(\alpha=0,2)$

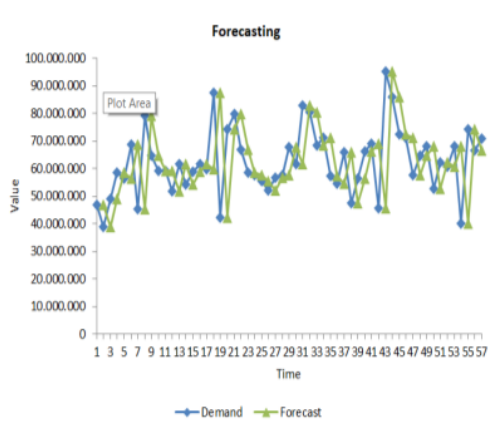

Gambar 3. Moving Average

\section{KESIMPULAN}

Hasil penelitian dapat disimpulkan bahwa model simple linear regression adalah model terbaik. jika peramalan model yang digunakan adalah model Single exponential, maka model dengan $\alpha$ $=0,2$ adalah model yang terbaik. Dari hasil kajian ini dapat dilihat bahwa perlu kehati-hatian dalam pemilihan model terutama dengan data yang berubah ubah, sehingga perlu dilakukan perbandingan dengan model lain yang mungkin akan menghasilkan nilai yang berbeda.

\section{DAFTAR PUSTAKA}

Faisol dan Aisah Siti. 2016. Penerapan Metode Exponential Smoothing Untuk Peramalan Jumlah Klaim di BPJS Kesehatan Pamekasan. 
Jurnal MANTIK (2)1:46-51.

Hadinata Novri. 2017. Penerapan Metode

Peternakan Ayam. Jurnal SISFOKOM 6(1):51-54.

Kamal, M. 1998. Bahan Pakan dan Ransum Ternak. Fakultas Peternakan, Universitas Gadjah Mada, Yogyakarta.

Nugraha YE dan Suletra IW. 2017. Analisis Metode Peramalan Permintaan Terbaik Produk Oxycan pada PT. Samator Gresik. Prosiding Seminar dan Konferensi Nasional IDEC. Halaman 414-422.

Rachman Rizal. 2018. Penerapan Penerapan Metode Moving Average dan Exponential Smoothing pada Peramalan Produksi Industri Garment. Jurnal INFORMATIKA 5(1): 211-220.

Subekti Endah. 2009. Ketahanan Pakan Ternak Indonesia. Jurnal Ilmu-Ilmu Pertanian 5(2):63-71.

Sukiyono K dan Rosdiana. 2018. Pendugaan Model Peramalan
Exponential Smoothing Dalam Peramalan Biaya Pengolahan Harga Beras Pada Tingkat Grosir. Jurnal Agrisep 17(1):23-30.

Sulistyono dan Sulistiyowati W. 2017. Peramalan Produksi dengan Metode Regresi Linier Berganda. Jurnal Prozima 1(2): 82-89

Wardah S dan Iskandar. 2016. Analisis Peramalan Penjualan Produk Keripik Pisang Kemasan Bungkus (Studi Kasus : Home Industry Arwana Food Tembilahan). Jurnal Teknik Industri 11(3):135-142.

Nurlifa AZ dan Kusumadewi S. 2017. Sistem Peramalan Jumlah Penjualan Menggunakan Metode Moving Average Pada Rumah Jilbab. Jurnal INOVTEK POLBENG 2(1):18-25.

Syam J, Tolleng AL dan Umar. 2016. Pengaruh Pemberian Pakan Konsentrat Dan Urea Molases Blok (UMB) Terhadap Hematokrit Sapi Potong. JIP Jurnal Ilmu dan Industri Peternakan 2(3):1-6. 